\title{
Phenological patterns and adaptations in an Artemisia/ Agropyron plant community
}

MICHAEL D. PITT AND BRIAN M. WIKEEM

\section{Abstract}

The phenology of 75 plant species belonging to an Artemisia tridentata Nutt./Agropyron spicatum (Pursh.) Scribn. \& Smith plant community in southem British Columbia was recorded in 1978 and 1979. Plant species were classified within 4 phenological groups that are hypothesized to reflect adaptation to spatial and temporal distribution of soil moisture. Summer Mature taxa (36 species, including 20 perennial forbs and 10 annual grasses and forbs) initiate growth early, flower rapidly, and mature before or soon after summer drought begins. Favorable moisture conditions in the fall may produce some rezrowth. Summer Qulescent taxa (27 species, including 8 of 9 perennial grasses) also initiate growth early in spring, develop fairly rapidly, but flower later than Summer Mature taxa, becoming only semidormant during summer drought. Significant regrowth often occurs in response to fall moisture. Protracted Growth taxa (4 species) display delayed spring growth, followed by fall flowering. These deeply rooted shrubs continue to grow and develop slowly throughout the frostfree period. Eight, generally shallowly rooted forbs were classified as Spring Ephemerals that initiate development very early in spring, flower and terminate growth before summer drought, and rarely resprout in fall. These 4 phenological groups provide flushes in botanical composition, forage production, and nutrient availability that should be reflected within grazing management and rangeland inventory programs.

Key Words: British Columbia, precipitation, soil moisture, steppe

Plant phenology describes the relationship between climatic factors and the respective developmental state of plant species (Daubenmire 1974). Awareness of such relationships is essential to understand fully the temporal and spatial ecological adaptations of plants within vegetation communities (White 1979).

\footnotetext{
Authors are associate professor, Department of Plant Science, University of British Columbia, Vancouver, Canada V6T 2A2; and research scientist, British Columbia Ministry of Forests, Research Branch, Kamloops, Canada V2B 8A9. At the time of the research the junior author was graduate student, Department of Plant Science, University of British Columbia.

Research was supported in part by the Natural Sciences and Engineering Research Council of Canada. Logistic and field support were provided by the British Columbia Ministry of Environment (Fish \& Wildlife Branch) and the Okanagan Game Farm. Sandra Wikeem assisted with field work.

Manuscript accepted 22 January 1990.
}

Although steppe vegetation characterized by Artemisia tridentata Nutt./ Agropyron spicatum (Pursh.) Scribn. \& Smith has been well described in terms of seral and climax dominants (e.g., Tisdale 1947, Daubenmire 1970, McLean 1970), few studies provide detailed, phenological attributes of these plant communities. Blaisdell (1958) reported seasonal development and yield for 23 species within Artemisia/Agropyron-dominated vegetation of southern Idaho, while Sauer and Uresk (1976) documented phenological patterns for 12 plant species within an Artemisia tridentata/Agropyron spicatum association of south-central Washington. Daubenmire (1972) contrasted annual cycles of soil moisture and temperature in 8 climax steppe communities of eastern Washington, while Cline et al. (1977) compared soil water use by Agropyron spicatum and Bromus tectorum L. as a function of phenological development.

For British Columbia, Tisdale (1947) proposed 3 floristic categories within Artemisia/Agropyron vegetation based on phenological patterns of 7 plant species. Subsequent phenological research in British Columbia has focused primarily on a few or single plant species (Tisdale et al. 1959, Harper 1969, Majak and McLean 1975, Stout et al. 1981, Quinton et al. 1982). This study documents phenological development of 75 plant species in an Artemisia tridentata/Agropyron spicatum bunchgrass stand of south-central British Columbia. These data, combined with patterns in precipitation, growing-degree-days, and soil moisture are interpreted relative to the phenological categories hypothesized by Tisdale (1947).

To facilitate communication, we recommend that more descriptive terminology replace Tisdale's (1947) numerical categories. Summer Mature species (Tisdale's Group 2) initiate growth early, flower rapidly, and mature before or soon after summer drought begins. Favorable moisture conditions in the fall may produce some regrowth, which for annual Summer Mature species normally occurs as germination. Summer Quiescent taxa (Tisdale's Group 1) also initiate growth early in spring, develop fairly rapidly, but flower later than Summer Mature taxa, becoming only semidormant during summer drought. Significant regrowth often occurs in response to fall moisture, with reflowering occasionally present. Protracted Growth taxa (Tisdale's Group 3) display 
delayed spring growth, followed by fall flowering. These species generally do not become quiescent during summer drought, but continue to develop slowly throughout the frost-free period.

\section{Study Area}

The 42-ha study area is located $10 \mathrm{~km}$ south of Penticton, British Columbia, west of Skaha Lake $\left(49^{\circ} 26^{\prime} \mathrm{N}, 119^{\circ} 37^{\prime} \mathrm{W}\right)$. Derived from glacial till, the soils are coarse-textured, and bedrock protrudes occasionally. Kelley and Spilsbury (1949) classified nearby soils as brown chernozems (Aridic Haploboroll) in the Skaha Gravelly Sandy Loam Series. Elevation of the generally steep sloping topography ranges from 550 to $750 \mathrm{~m}$ with north and northeast exposures.

Chapman (1952) described the climate as Middle Latitude Steppe (BSk) according to the Koppen classification. Annual precipitation at Penticton airport, $6 \mathrm{~km}$ north of the study site, averages $296.1 \mathrm{~mm}$, with bimodal peaks in January $(31.5 \mathrm{~mm})$ and June $(35.6 \mathrm{~mm})$. Highest mean daily maximum temperatures occur in July $\left(28.6^{\circ} \mathrm{C}\right)$; coldest daily mean minimum temperatures prevail in January $\left(-5.6^{\circ} \mathrm{C}\right)$. The frost free period averages 143 days (Environment Canada 1974).

The vegetation is transitional between the Artemisia tridentata and Pinus ponderosa Dougl. zones classified by McLean (1970). Dominant herbaceous plants included Agropyron spicatum, Bromus tectorum, Koeleria cristata Pers., Stipa comata Trin. \& Rupr., Balsamorhiza sagittata (Pursh) Nutt., and Poa pratensis $\mathrm{L}$. in moist draws. Dominant woody species included Pinus ponderosa and Artemisia tridentata subsp. tridentata, with Amelanchier alnifolia Nutt., Acer glabrum Nutt., Prunus virginiana L., and Symphoricarpos albus (L.) Blake occurring in the draws. Plant taxonomy follows Hitchcock and Cronquist (1973).

\section{Methods}

Between 1977 and 1979, foliar cover (\%) and botanical composition (\%) of total foliar cover for all plant species were determined mid-monthly (April to August) by sampling 36 transects evenly distributed over the study area. Each $30-\mathrm{m}$ transect provided a sample point of botanical composition and foliar cover, comprised of 100,1.9-cm diameter loops, spaced at 30-cm intervals (Parker 1951). Foliar cover equalled frequency of each species/ 100 loops. Botanical composition equalled the proportion of total foliar cover for each species along each transect. Differences between years and among months in mean botanical composition and cover of species were determined with orthogonal contrasts or the Student-
Newman-Keul's procedure following ANOVA.

Phenological trends were documented for 75 plant taxa. Sampling occurred mid-monthly from March 1978 to December 1979. Phenological development for each species was determined with 10 plants during each sampling period. Plants were selected subjectively to characterize modal phenological development on the study site. At each sample period, 1 of the following 6 growth stages (Sauer and Uresk 1976) was recorded for each plant species: (1) Growth initiation; (2) Flora initiation; (3) Full flower; (4) Seed set and shatter; (5) Cured; and (6) Fall regrowth or germination.

Soil moisture was recorded at 2 mid-slope sites located on a north- and east-facing aspect. Two stations/site were monitored mid-monthly throughout the growing season, from March to November, 1977-1979. At each station, available soil moisture (\%) was determined with 4 gypsum soil moisture blocks located at $2-\mathrm{cm}$ and 35-cm depths. All measurements occurred at noon to minimize the effects of daily cycles. Precipitation and growing-degree-days data (1977-1979) were provided by Environment Canada at the Penticton Airport $10 \mathrm{~km}$ north of the study area.

\section{Results}

The phenological observations reported here likely reflect typical patterns for steppe vegetation of southern British Columbia, as annual precipitation conformed closely to 30-year averages (Table 1). Moreover, cumulative precipitation throughout the growing season (1 March-31 October) in $1977(191.8 \mathrm{~mm}) ; 1978$ (223.1 $\mathrm{mm})$; and $1979(207.4 \mathrm{~mm})$ only slightly exceeded the regional normal of $187.7 \mathrm{~mm}$ (Table 1).

Total growing-degree-days above $5^{\circ} \mathrm{C}$ in $1977(2,174.6)$ and $1978(2,107.9)$ differed little from the 30-year average $(2,119.3)$, although growing-degree-days during $1979(2,335.3)$ slightly exceeded long-term averages. During the period of most rapid plant growth (1 April-30 June), absolute differences in growing-degreedays were negligible, with 106,96 , and $104 \%$ of normal attained in 1977, 1978, and 1979 respectively (Environment Canada 1974, $1977,1978,1979$ ).

The classification of plant species based on phenological patterns is summarized in Table 2. Eighty-four percent of the taxa displayed either Summer Mature or Summer Quiescent patterns, comprising 36 and 27 plant species, respectively (Table 3 ). Only 4 species exhibited phenological patterns characterized as Protracted Growth. Eight species demonstrated patterns that were not described by Tisdale (1947). We recommend that these taxa be classified as Spring Ephemeral, which germinate very early in

Table 1. Montnly and annual rainfall (mm), snowfall (cm) and total precipitation (mm), 1977-19791 and 30-year normals (1941-19702), Penticton, British Columbia.

\begin{tabular}{|c|c|c|c|c|c|c|c|c|c|c|c|c|}
\hline \multirow[b]{2}{*}{ Month } & \multicolumn{3}{|c|}{1977} & \multicolumn{3}{|c|}{1978} & \multicolumn{3}{|c|}{1979} & \multicolumn{3}{|c|}{$1941-1970$} \\
\hline & Rain & Snow & Total & Rain & Snow & Total & Rain & Snow & Total & Rain & Snuw & Total \\
\hline Jan. & 11.3 & 16.8 & 26.3 & 5.4 & 45.8 & 37.3 & 0.0 & 30.0 & 20.1 & 8.9 & 24.9 & 31.5 \\
\hline Feb. & 3.9 & 3.5 & 7.4 & 14.6 & 16.6 & 26.7 & 9.0 & 9.4 & 13.9 & 10.4 & 10.9 & 20.8 \\
\hline Mar. & 6.8 & 11.8 & 18.2 & 12.8 & 0.2 & 13.0 & 11.1 & $\mathrm{~T}^{3}$ & 11.1 & 12.2 & 4.6 & 16.5 \\
\hline Apr. & 14.5 & $T$ & 15.3 & 60.4 & 0.0 & 60.4 & 10.5 & $\mathrm{~T}$ & 10.5 & 22.9 & 0.3 & 23.1 \\
\hline May & 61.9 & 0.0 & 61.9 & 21.2 & $\mathrm{~T}$ & 21.2 & 29.2 & 0.0 & 29.2 & 27.7 & 0.0 & 27.7 \\
\hline June & 9.3 & 0.0 & 9.3 & 18.5 & 0.0 & 18.5 & 14.6 & 0.0 & 14.6 & 35.6 & 0.0 & 35.6 \\
\hline July & 19.9 & 0.0 & 19.9 & 26.0 & 0.0 & 26.0 & 28.0 & 0.0 & 28.0 & 24.6 & 0.0 & 24.6 \\
\hline Aug. & 30.5 & 0.0 & 30.5 & 44.9 & 0.0 & 44.9 & 49.2 & 0.0 & 49.2 & 22.4 & 0.0 & 22.4 \\
\hline Sep. & 34.0 & 0.0 & 34.0 & 36.8 & 0.0 & 36.8 & 37.7 & 0.0 & 37.7 & 18.0 & 0.0 & 18.0 \\
\hline Oct. & 2.7 & 0.0 & 2.7 & 2.3 & 0.0 & 2.3 & 27.1 & 0.0 & 27.1 & 19.8 & $\mathrm{~T}$ & 19.8 \\
\hline Nov. & 21.8 & 9.1 & 32.6 & 18.8 & 3.7 & 24.3 & 5.8 & $\mathrm{~T}$ & 5.8 & 19.3 & 6.9 & 25.7 \\
\hline Dec. & 29.3 & 33.4 & 58.3 & 0.0 & 18.7 & 14.3 & 9.4 & 23.9 & 31.0 & 10.4 & 21.6 & 30.5 \\
\hline Annual & 245.9 & 74.6 & 316.4 & 228.7 & 84.9 & 325.7 & 231.6 & 63.3 & 278.2 & 232.2 & 69.2 & 296.2 \\
\hline
\end{tabular}

'Environment Canada (1977, 1978, 1979).

2Environment Canada (1974).

${ }^{3} \mathrm{~T}=$ Trace. 
Table 2. Mid-monthly phenolony of 75 plant species associated with an Artemisia/Agropyron community1.

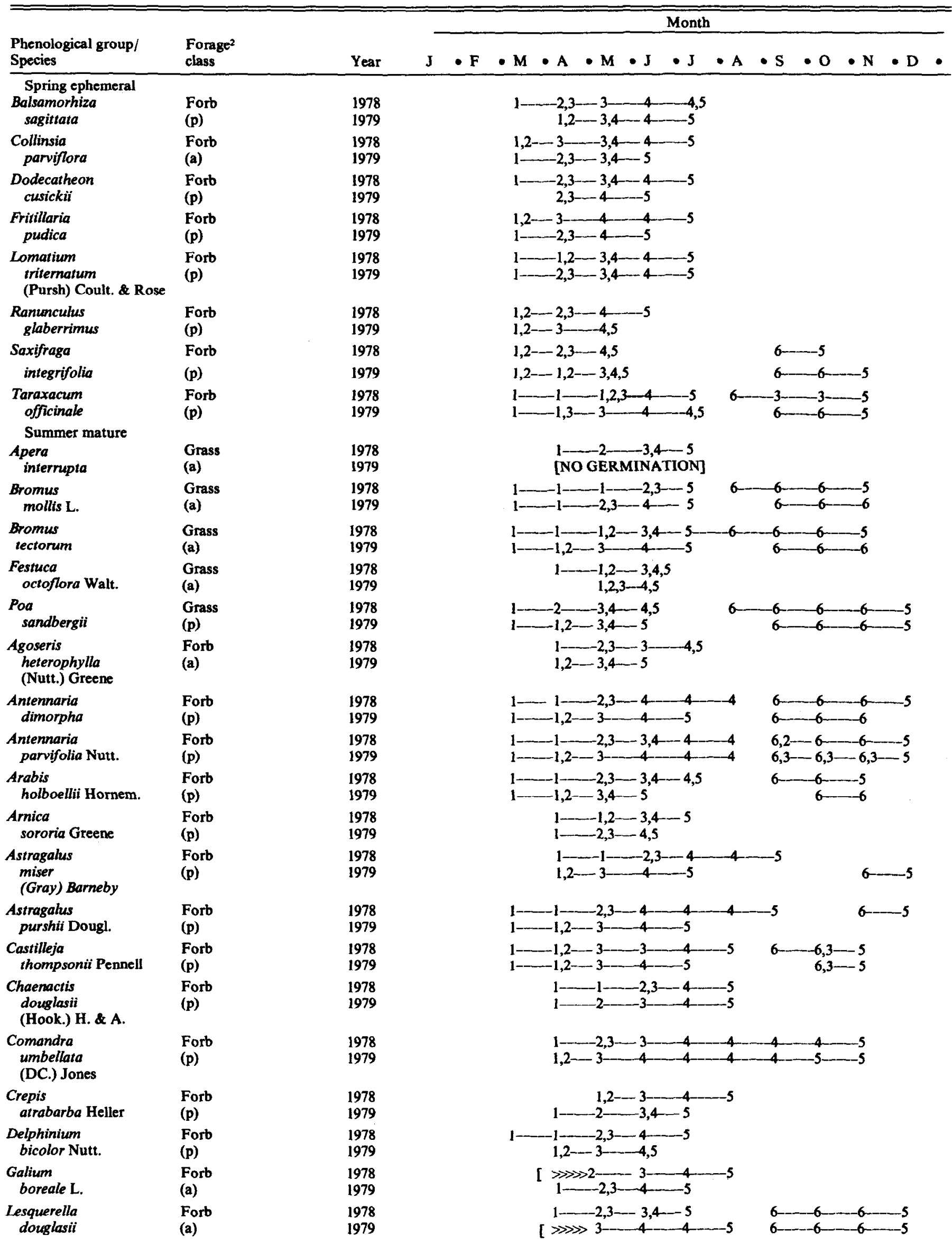


Table 2. Continued.

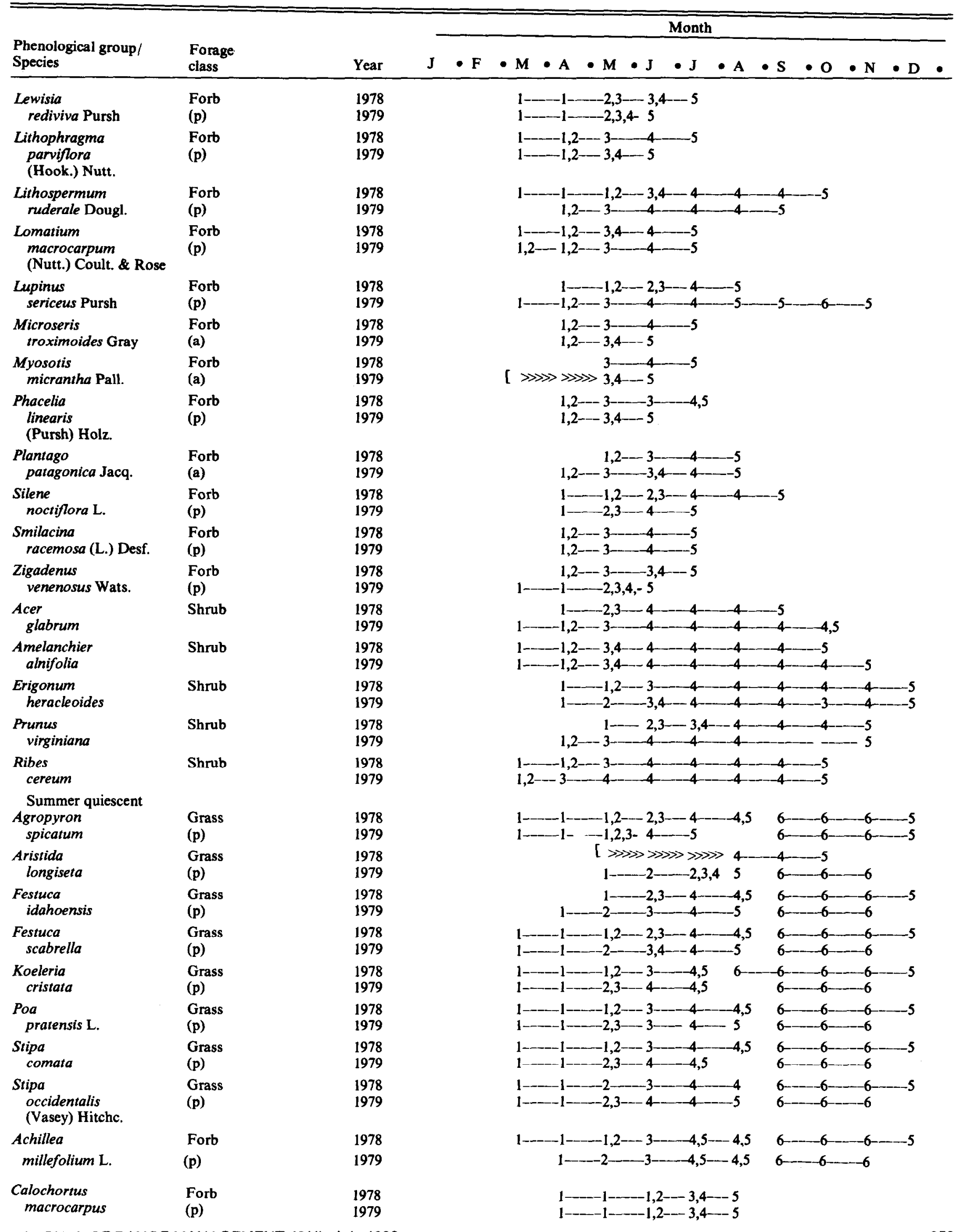


Table 2. Continued.

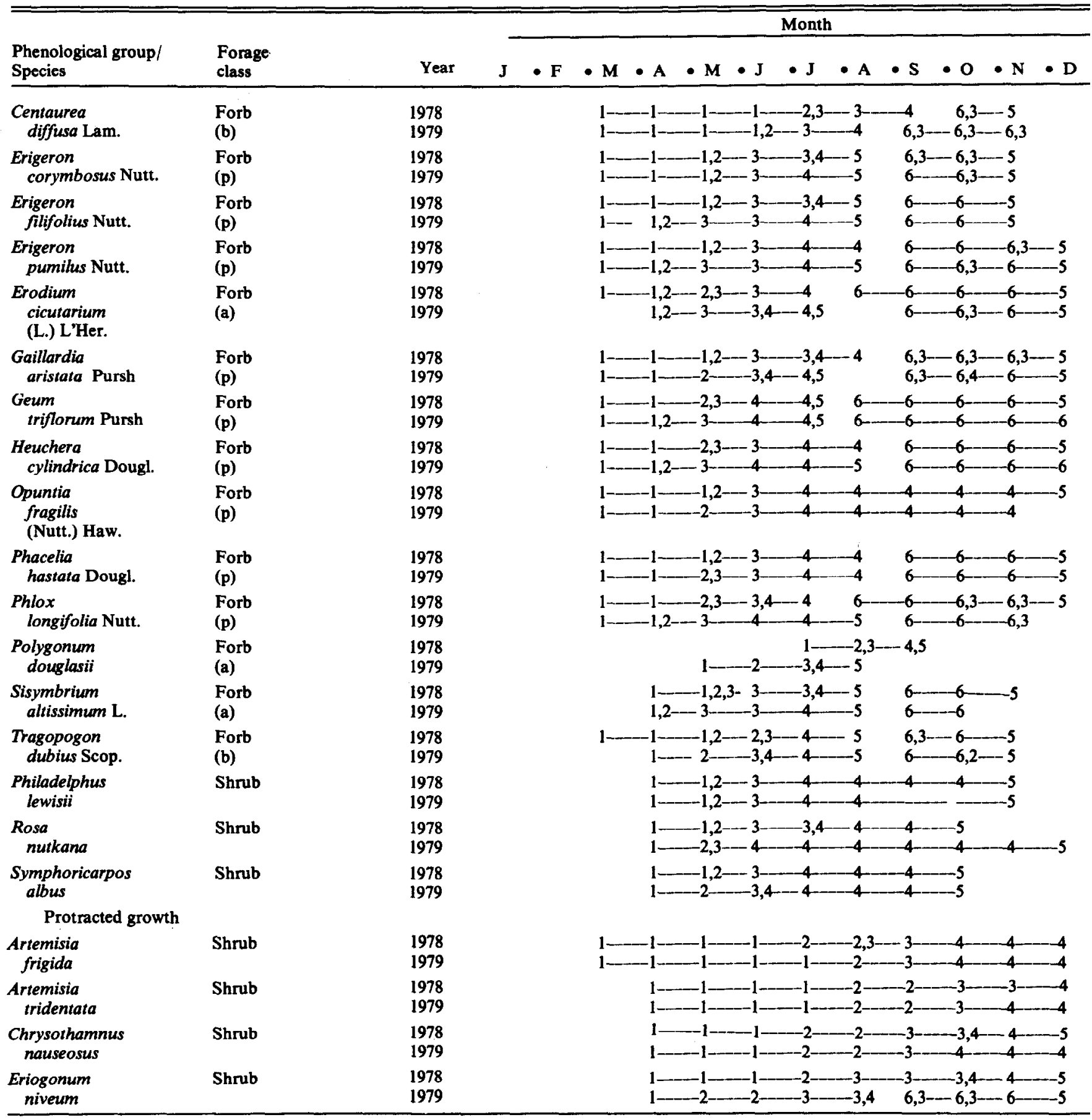

'Phenological Stage: $\gg \gg \gg=$ No Observations; 1 = growth initiation; 2 = Floral initiation; 3 = Full flower; 4 = Seed set and shatter; $5=$ Cured; $6=$ Fall regrowth or germinati 2Forage Class: $\mathbf{a}=$ annual; $\mathbf{b}=$ biennial; $\mathbf{p}=$ perennial.

spring, flower and terminate growth before summer drought, and rarely resprout in fall.

Specific combinations of life forms characterized each of the 4 phenological groups. Spring Ephemerals, consisting entirely of forbs, 7 of which were perennial, initiated growth early in March and typically flowered by mid-May in both 1978 and 1979 (Table 2). Only Saxifraga integrifolia Hook. and Taraxacum officinale Weber produced fall regrowth in either year: the former through regrowth of established plants and the latter with fall germination of disseminated seeds.

Although Summer Mature taxa consisted primarily of perennial forbs, this phenological pattern also contained the largest number of annual grasses and forbs (Table 3). This mixture of life forn and longevity among Summer Mature taxa produced wide vari bility in growth initiation dates, which generally ranged betwe early March and the beginning of April (Table 2). These ta normally completed flowering by mid-May to early June. Summ Mature plants displayed some fall regrowth or germinatic although only 11 species resumed growth between August a! November during both 1978 and 1979 . Regrowth was common 1 Poa sandbergii in both years, with tiller lengths reaching 8-10 c in 1978 and $4-6 \mathrm{~cm}$ in 1979. Fall-germinated Bromus tector displayed substantial growth in September and October of 19 and 1979 , producing tillers from $7-10 \mathrm{~cm}$ in both years. Neitr 
Table 3. Number of species represented in each phenological group at the Okanagan Game Farm.

\begin{tabular}{lcccc}
\hline \hline Life form & $\begin{array}{c}\text { Spring } \\
\text { ephemeral }\end{array}$ & $\begin{array}{c}\text { Summer } \\
\text { mature }\end{array}$ & $\begin{array}{c}\text { Summer } \\
\text { quiescent }\end{array}$ & $\begin{array}{c}\text { Protracted } \\
\text { growth }\end{array}$ \\
\hline Annual grass & 0 & 4 & 0 & 0 \\
Perennial grass & 0 & 1 & 8 & 0 \\
Annual forb & 1 & 6 & 3 & 0 \\
Biennial forb & 0 & 0 & 2 & 0 \\
Perennial forb & 7 & 20 & 11 & 0 \\
Shrub & 0 & 5 & 3 & 4 \\
Total & 8 & 36 & 27 & 4 \\
\hline
\end{tabular}

species, however, generated seed stalks during fall regrowth.

The 27 Summer Quiescent species also included a relatively large number of perennial forbs, plus 8 of 9 perennial grasses. This phenological group generally initiated vegetative growth in March, although Aristida longiseta Steud., Festuca idahoensis Elmer, Calochortus macrocarpus Dougl., Philadelphus lewisii Pursh., Rosa nutkana Presl, and Symphoricarpos albus all typically started in early April (Table 2). Floral initiation normally occurred later than for Summer Mature plants, ranging from mid-May to mid-July. Most species (21) came to full flower during June.

Of the 27 Summer Quiescent species, all but 5 produced fall regrowth in both sample years. Regrowth tiller lengths of Agropyron spicatum, Koeleria cristata, and Stipa comata averaged $16-18,8-10$, and $20-25 \mathrm{~cm}$, respectively, in 1978 and, 8-12, 6-8, and $10-12 \mathrm{~cm}$ respectively, in 1979 . None of these 3 species, however, produced seed stalks during fall regrowth.

The 4 Protracted Growth species, comprised only of shrubs, generally began growth later, in April, and usually did not flower until September or October (Table 2). Following flowering, these shrubs produced no visible curing, and normally remained green, even during winter. Only Eriogonum niveum Dougl. flowered twice in a single year.

Phenological distinctions among the $\mathbf{4}$ groups remained similar from one year to the next, as $\mathbf{5 7}$ of the 75 plant species initiated growth during the same sampling period in 1978 and 1979 (Table 4). Protracted Growth species were the most consistent (4/4),

Table 4. Number of species reaching phenological development stages in 1979 compared to 1978.

\begin{tabular}{lrrrrr}
\hline \hline & \multicolumn{5}{c}{ Growth stage } \\
\cline { 2 - 6 } Phenological group & 1 & 2 & 3 & 4 & 5 \\
\hline Spring ephemeral & 7 & 3 & 1 & 4 & 1 \\
$\quad$ Same & 0 & 2 & 3 & 3 & 5 \\
$\quad$ Earlier & 1 & 3 & 4 & 1 & 2 \\
Later & & & & & \\
Summer mature & 24 & 16 & 24 & 13 & 12 \\
Same & 9 & 18 & 11 & 21 & 20 \\
Earlier & 3 & 2 & 1 & 2 & 4 \\
Later & & & & & \\
Summer quiescent & 22 & 18 & 16 & 14 & 16 \\
Same & 2 & 9 & 11 & 13 & 10 \\
Earlier & 3 & 0 & 0 & 0 & 1 \\
$\quad$ Later & & & & & \\
Protracted growth & 4 & 2 & 2 & 2 & 2 \\
$\quad$ Same & 0 & 0 & 0 & 1 & 0 \\
Earlier & 0 & 2 & 2 & 1 & 2 \\
$\quad$ Later & & &
\end{tabular}

'The codes $1,2,3,4$, and 5 refer to Growth Initiation, Floral Initiation, Full Flower, Seed Set and Shatter, and Cured, respectively. followed by the Spring Ephemeral (7/8), Summer Quiescent (22/27), and Summer Mature (24/36) phenological groups.

Among spring Ephemerals, spring growth initiation differed only for Balsamorhiza sagittata, which began growth about 1 month later in 1979 compared to 1978 (Table 4; Table 2). Five of 8 Spring Ephemerals completed growth 1 month earlier in 1979 compared to 1978 (Table 4).

Phenological maturity also occurred earlier in 1979 for Summer Mature and Summer Quiescent species (Table 4). Twenty of 36 Summer Mature and 10 of 27 Summer Quiescent species matured earlier in 1979, whereas only 3 (Lesquerella douglasii Wats., Acer glabrum, Amelanchier alnifolia) of $\mathbf{3 6}$ and one (Rosa nutkana) of 27, respectively, matured later. Apera interrupta (L.) Beauv., a Summer Mature annual grass, failed to germinate in 1979 (Table 2).

Blaisdell (1958) also demonstrated that the chronological sequence of flowering for 23 steppe species in Idaho remained constant, even though the specific date at which individual species reached particular stages of development differed widely over a 7-year period. Similar results, albeit for fewer plant taxa, were reported by Tisdale et al. (1959) and Harper (1969) in British Columbia.

\section{Phenological Patterns}

Spring Ephemeral species typically achieved maximum foliar cover and botanical composition during May, declining $(P<0.05)$ thereafter, and never exceeded $7.0 \%$ botanical composition after June 15 (Table 5). Spring Ephemerals responded $(P<0.05)$ to

Table 5. Average mid-monthly (April-August) foliar cover (\%) and botanical compoistion (\%) of phenological groups, 1977-1979.

\begin{tabular}{|c|c|c|c|c|c|c|c|c|}
\hline \multirow[b]{2}{*}{$\begin{array}{r}\text { Month } \\
\text { Year }\end{array}$} & \multicolumn{2}{|c|}{$\begin{array}{c}\text { Spring } \\
\text { ephemeral }\end{array}$} & \multicolumn{2}{|c|}{$\begin{array}{c}\text { Summer } \\
\text { mature }\end{array}$} & \multicolumn{2}{|c|}{$\begin{array}{c}\text { Summer } \\
\text { quiescent }\end{array}$} & \multicolumn{2}{|c|}{$\begin{array}{c}\begin{array}{c}\text { Protracted } \\
\text { growth }\end{array} \\
\end{array}$} \\
\hline & Cov. & $\begin{array}{l}\text { Bot. } \\
\text { comp }\end{array}$ & Cov. & $\begin{array}{l}\text { Bot. } \\
\text { comp. }\end{array}$ & Cov. & $\begin{array}{l}\text { Bot. } \\
\text { comp. }\end{array}$ & Cov. & $\begin{array}{l}\text { Bot. } \\
\text { comp. }\end{array}$ \\
\hline \multicolumn{9}{|l|}{ Apr. } \\
\hline 1977 & 3.3 & 5.8 & 15.2 & 27.7 & 25.8 & 42.9 & 9.6 & 14.7 \\
\hline 1978 & 9.5 & 14.5 & 21.4 & 34.0 & 23.3 & 35.4 & 8.2 & 11.0 \\
\hline 1979 & 4.0 & 6.5 & 21.3 & 36.9 & 23.6 & 39.3 & 8.4 & 12.5 \\
\hline \multicolumn{9}{|l|}{ May } \\
\hline 1977 & 4.2 & 6.0 & 19.1 & 29.4 & 31.5 & 46.6 & 9.0 & 12.2 \\
\hline 1978 & 14.3 & 19.0 & 22.4 & 31.5 & 25.8 & 33.5 & 8.2 & 10.0 \\
\hline 1979 & 4.6 & 7.1 & 18.0 & 30.8 & 29.4 & 47.7 & 7.4 & 10.6 \\
\hline \multicolumn{9}{|l|}{ June } \\
\hline 1977 & 3.2 & 4.2 & 19.9 & 29.3 & 36.1 & 50.8 & 8.3 & 10.5 \\
\hline 1978 & 6.2 & 8.2 & 26.5 & 35.9 & 31.4 & 41.5 & 7.9 & 9.2 \\
\hline 1979 & 3.6 & 6.5 & 12.2 & 23.4 & 28.5 & 51.4 & 7.7 & 13.1 \\
\hline \multicolumn{9}{|l|}{ July } \\
\hline 1977 & 1.3 & 2.4 & 15.5 & 26.1 & 29.5 & 51.8 & 8.5 & 13.6 \\
\hline 1978 & 4.7 & 7.0 & 21.4 & 32.2 & 29.0 & 42.1 & 9.3 & 12.0 \\
\hline 1979 & 1.4 & 3.0 & 12.8 & 24.3 & 29.8 & 53.9 & 8.0 & 13.4 \\
\hline \multicolumn{9}{|l|}{ Aug. } \\
\hline 1977 & 1.9 & 3.5 & 15.8 & 26.5 & 31.7 & 50.7 & 8.6 & 12.7 \\
\hline 1978 & 2.3 & 3.8 & 14.5 & 25.6 & 28.7 & 50.4 & 9.3 & 13.7 \\
\hline 1979 & 0.6 & 1.4 & 9.5 & 20.8 & 25.6 & 55.5 & 7.8 & 15.4 \\
\hline
\end{tabular}

annual weather patterns, peaking at $19.0 \%$ botanical composition in May 1978, when April precipitation equalled $60.4 \mathrm{~cm}$ (Table 1). During May of 1977 and 1979, Spring Ephemerals peaked at only 6.0 and $7.1 \%$ botanical composition, following substantially lower April precipitation.

Monthly trends for Summer Mature species also varied $(P<0.05)$ over the 3-year period, although the relative fluctuations were less than those recorded for Spring Ephemerals. In 1979, foliar cover and botanical composition peaked in April, whereas maximum values in 1977 and 1978 occurred in May and June, respectively. Moreover, foliar cover (9.5\%) and botanical composition (20.8\%) 
in August 1979 declined $(P<0.05)$ to lower levels than either 1977 or 1978 (Table 5). These 1979 trends may have resulted from the dry spring, which produced only $21.6 \mathrm{~cm}$ of precipitation during March and April (Table 1).

The Summer Mature group contained 10 of 14 annual plant species, which persisted throughout spring, despite generally low moisture availability. For example, April botanical composition of Bromus tectorum peaked in 1979 at $20.1 \%$. Annual plants, however, cure and shatter quickly following maturity. Foliar cover of Bromus tectorum equalled only $7.9 \%$ in August 1979, which comprised most of the $9.5 \%$ August foliar cover observed for Summer Mature species.

Although monthly trends in botanical composition and foliar cover also differed $(P<0.05)$ among years for Summer Quiescent species, the magnitude of these differences were small compared to the Spring Ephemeral and Summer Mature groups. Over the 3-year period, foliar cover varied between a narrow range of 23.3-36.1\%, with minimum and maximum values normally occurring in April and June, respectively (Table 5).

Botanical composition of Summer Quiescent species peaked later during the year compared to foliar cover, reaching maximum values in August. This group, dominated by perennial grasses, increases in botanical composition throughout the growing season, as Spring Ephemeral and Summer Mature species mature and shatter. Agropyron spicatum comprised the single largest component of the Summer Quiescent group, averaging $40.0 \%$ botanical composition during August over the 3-year period.

Foliar cover and botanical composition of Protracted Growth species remained relatively stable over the 3-year period. Differences $(P<0.05)$ in average monthly foliar cover were negligible, ranging from a low of $7.4 \%$ in May 1979 to $9.6 \%$ in April 1977. Botanical composition of these 4 shrubs similarly remained relatively constant, and varied primarily in response to seasonal abundance of herbaceous plant species.

\section{Discussion}

Our results expand the number of taxa within 3 phenological groups proposed by Tisdale (1947). The Summer Quiescent category contains not only Agropyron spicatum and Stipa comata, but also includes 25 other species demonstrating early growth followed by semi-dormancy during summer drought. Tisdale's Group 2 (Summer Mature species) contained Poa sandbergii, Antennaria dimorpha (Nutt.) T. \& G. and Bromus tectorum, whereas our study identifies 33 additional, generally low-growing taxa that normally cease or significantly reduce growth during summer drought. Protracted Growth species, in addition to Artemisia tridentata and Chrysothamnus nauseosus (Pall.) Britt. reported for Tisdale's Group 3, also include Artemisia frigida Willd. and Eriogonum niveum.

Spring Ephemerals were not included in Tisdale's (1947) original classification. The phenology of these plants, characterized by early growth and reproduction, combined with virtually no fall regrowth or germination, clearly sets these species apart from other steppe taxa.

\section{Relationship of Plant Phenology to Ambient and Soil Moisture}

The 4 phenological groups are likely adapted to use soil moisture within different portions of spatial and temporal gradients (Tisdale 1947, Sauer and Uresk 1976, Cline et al. 1977). Spring Ephemerals are shallowly rooted forbs, which may have evolved an early growth pattern to avoid summer drought (Sauer and Uresk 1976). Summer mature species resume growth slightly later than Spring Ephemerals, but also avoid summer drought by ceasing growth. Unlike Spring Ephemerals, Summer Mature taxa may renew growth in the fall when soil moisture and air temperature become
Table 6. Percent soil moisture ( $x \pm \mathrm{SE}, n=15), 1977-19791$, Penticton, British Columbia.

\begin{tabular}{lrccc}
\hline & & & Soil moisture & \\
\cline { 2 - 5 } Month & $\begin{array}{c}\text { Depth } \\
(\mathrm{cm})\end{array}$ & 1977 & 1978 & 1979 \\
\hline Mar. & 2 & $\mathrm{ND}^{2}$ & $77.8 \pm 0.4$ & $71.5 \pm 2.9$ \\
& 35 & $\mathrm{ND}$ & $79.1 \pm 2.4$ & $72.2 \pm 0.8$ \\
Apr. & 2 & $35.0 \pm 1.8$ & $83.5 \pm 2.6$ & $58.6 \pm 3.7$ \\
& 35 & $52.7 \pm 0.4$ & $81.7 \pm 0.5$ & $70.5 \pm 1.2$ \\
May & 2 & $\mathrm{ND}$ & $91.1 \pm 2.9$ & 0.0 \\
& 35 & $\mathrm{ND}$ & $86.9 \pm 0.6$ & $4.6 \pm 2.7$ \\
June & 2 & $\mathrm{ND}$ & $38.3 \pm 6.6$ & $21.5 \pm 3.4$ \\
& 35 & $\mathrm{ND}$ & $36.6 \pm 9.3$ & 0.0 \\
July & 2 & 0.0 & $6.5 \pm 3.3$ & 0.0 \\
& 35 & 0.0 & 0.0 & 0.0 \\
Aug. & 2 & 0.0 & $60.1 \pm 4.0$ & $71.8 \pm 4.0$ \\
& 35 & 0.0 & $7.8 \pm 1.4$ & 0.0 \\
Sep. & 2 & 0.0 & $60.3 \pm 2.4$ & $\mathrm{ND}$ \\
& 35 & 0.0 & $14.1 \pm 5.4$ & $\mathrm{ND}$ \\
Oct. & 2 & $19.2 \pm 3.0$ & 0.0 & $2.0 \pm 1.4$ \\
& 35 & 0.0 & 0.0 & 0.0 \\
Nov. & 2 & $38.7 \pm 4.8$ & 0.0 & ND \\
& 35 & 0.0 & 0.0 & ND \\
\hline
\end{tabular}

'Averaged over the north- and east-facing sample sites.

${ }^{2}$ No data due to equipment failure.

more favorable. Summer Quiescent species become only scmidormant during summer drought, and normally use fall moisture for continued growth and reproduction. This adaptation creates risk during cycles of lower than normal precipitation, as reproductive output of large, caespitose grasses such as Agropyron spicatum and Festuca scabrella Torr. is notoriously variable (Stout et al. 1981, Quinton et al. 1982). This disadvantage during dry years is offset by the ability of Summer Quiescent species to regrow vigorously during moist autumn periods, which occurred during September of 1978 and 1979. Protracted Growth species, primarily deeply rooted shrubs such as Artemisia tridentata, obtain soil moisture at depths beyond the reach of their herbaceous associates (Tisdale 1947) and capitalize on all favorable growing conditions during the frost-free period.

These phenological adaptations were evident throughout the 3 -year study. For example, soil moisture at the 2-and 35-cm depths remained high in all 3 years during A pril (Table 6), which provided sufficient moisture for growth and reproduction of Spring Ephemerals. Nonetheless, phenological variability occurred among years, depending on total precipitation. For example, 5 of 8 Spring Ephemerals (Balsamorhiza sagittata, Collinsia parviflora Lind., Dodecatheon cusickii Greene, Fritillaria pudica (Pursh) Spring., Ranunculus glaberrimus Hook.) completed growth 1 month earlier in 1979 compared to 1978 (Table 4), perhaps reflecting reduced precipitation in April 1979 compared to April 1978 (Table 1). April soil moisture at the 2-and 35-cm depths was also lower in 1979 compared to 1978 (Table 6), with botanical composition in May 1979 substantially lower than May 1978 (Table 5). Lowest soil moisture in April occurred in 1977, followed by the lowest May botanical composition for Spring Ephemerals.

Tisdale (1947) reported that the rooting depth of Poa sandbergii, a dominant, perennial Summer Mature species, rarely exceeds 30 $\mathrm{cm}$. Botanical composition and foliar cover of Poa sandbergii peaked on 15 April of each year, (Wikeem 1984:92), which preceded depleted soil moisture at the 35-cm depth on 15 May in both 1977 and 1979 (Table 6). Even in 1978, when soil moisture at the $35-\mathrm{cm}$ depth remained high until 15 June, botanical composition and foliar cover of Poa sandbergii declined after 15 May, illustrat- 
ing this species' adaptation for early maturation.

Bromus tectorum comprised more than half of the June-August foliar cover of the Summer Mature phenological group (Wikeem 1984:91-92). Although Tisdale (1947) indicated that maximum rooting depth of Bromus tectorum in British Columbia occurred at $30 \mathrm{~cm}$, Harris and Goebel (1976) documented root penetration of this annual grass to depths of $1.0 \mathrm{~m}$. Bromus tectorum may, therefore, benefit from soil moisture being available at or below the $35-\mathrm{cm}$ depth until flowering is completed in June. The Summer Mature group, characterized by phenological patterns of Bromus tectorum, therefore peaked in June botanical composition and foliar cover in 1978 (Table 5), when soil moisture at the 35-cm depth remained above $30 \%$ until June 15 (Table 6 ). In contrast, soil moisture in 1979 at the $35-\mathrm{cm}$ depth averaged only $4.6 \%$ on 15 May, with no measurable moisture available in June. Correspondingly, June 1979 botanical composition and foliar cover of Summer Mature plants (Table 5) and of Bromus tectorum (Wikeem 1984:92) were below 1978 values.

Summer Quiescent plants generally flower and mature later than Summer Mature taxa and were not negatively affected by low soil moisture at the 35-cm depth in May 1979. The usual rooting depth of the dominant Summer Quiescent species, Agropyron spicatum, exceeds $1.0 \mathrm{~m}$ (Harris and Goebel 1976). Although no moisture data were collected at this depth, botanical composition and foliar cover of the Summer Quiescent phenological group displayed no consistent trends in response to variable annual precipitation. Indeed, only in 1979 did precipitation from 1 March to 31 July $(93.4 \mathrm{~mm})$ fall below the 30 -year normal of $127.5 \mathrm{~mm}$ (Table 1 ). Botanical composition of Summer Quiescent species, however, was generally highest in 1979 , suggesting that soil moisture below $35 \mathrm{~cm}$ remained sufficient for this phenological group throughout the 3-year period.

Trends in foliar cover and botanical composition of the Summer Quiescent group are characterized best by Agropyron spicatum, which represented 67.3 and $77.4 \%$ of total foliar cover for this phenological group, even during peak foliar cover periods in June 1978 and 1979, respectively. Maximum foliar cover of Agropyron spicatum also occurred in June 1978 and 1979 , equalling $24.3 \%$ in both years (Wikeem 1984:92). Lowest botanical composition (19.0\%) was recorded in April 1978, corresponding to the lowest April botanical composition for Summer Quiescent taxa (Table 5). The second 2 most prevalent Summer Quiescent species (Koeleria cristata and Stipa comata) also peaked in foliar cover and botanical composition during summer months, following lowest values in spring (Wikeem 1984:92).

The Protracted Growth phenological group displayed little variation in annual or monthly botanical composition and foliar cover. The deeply rooted, dominant species, Artemisia tridentata, remains a relatively constant component of the plant community despite annual variability in ambient and soil weather patterns. Lowest botanical composition occurred in May $(9.0 \%)$, with maximum values recorded in August (11.5\%).

\section{Conclusions}

These phenological patterns obviously represent a continuum of responses. Boundaries between subjective, phenological categories are therefore occasionally indistinct. For example, Calochortus macrocarpus, Polygonum douglasii Greene, Philadelphus lewisii, Rosa nutkana, and Symphoricarpos albus all failed to produce fall regrowth. Yet these species were still categorized as Summer Quiescent because flowering normally occurred in June and July rather than May and June, which characterized Summer Mature taxa. Similarly, Acer glabrum, Amelanchier alnifolia, Eriogonum heracleoides Nutt., Prunus virginiana, and Ribes cereum Dougl. were all classified as Summer Mature due to early flowering between April and June, even though the foliage on all 5 species remained green throughout the summer period. These and other examples of plant species displaying characteristics of more than 1 phenological category suggest that these 4 categories should be interpreted as broad, ecological spectra, rather than rigid, mutually exclusive adaptations.

The phenological patterns displayed within Artemisia/Agropyron steppe communities provide ecological constraints and opportunities for vegetation management and assessment. The 4 phenological groups reported here provide flushes in forage production and nutrient availability, which in turn determine the variety of animal species which may be supported by these plant communities (Sauer and Uresk 1976). Management programs that eliminate or reduce taxa within phenological groups may severely limit the reproductive success of wildlife species, may preclude optimum habitat for indigenous pollinating insects, or may shorten the calendar periods of economic livestock grazing opportunities.

Rangeland inventory and grazing management programs should reflect these pulses in species composition, forage production, and nutrient availability. Most inventory programs are based on maximum herbage production of key management species within plant communities or habitat types. Sampling periods should, therefore, correspond to the growth period(s) of specific phenological groups containing these key management species. Less precise sampling schemes necessarily confound maximum herbage production with normal, seasonal changes in herbage accumulation and/or weathering (Ratliff and Heady 1962). Similarly, proper livestock stocking rates within pastures should be based on forage available during the period of grazing rather than on peak forage production, which may occur either before or after period(s) of livestock grazing. Our observations provide guidelines for such considerations.

\section{Literature Cited}

Blaisdell, J.P. 1958. Seasonal development and yield of native plants on the upper Snake River Plains and their relation to certain climatic factors. USDA Tech. Bull. 1190, USDA, Washington, D.C.

Chapman, J.D. 1952. The climate of British Columbia. B.C. Nat. Resour. Conf. 5:8-54.

Cline, J.F., D.W. Uresk, and W.H. Rickard. 1977. Comparison of soil water used by a sagebrush-bunchgrass and a cheatgrass community. J. Range Manage. 30:199-201.

Daubenmire. R. 1970. Steppe vegetation of Washington. Wash. Agr. Exp. Sta. Tech. Bull. 62, Washington State Univ., Pullman.

Daubenmire, R. 1972. Annual cycles of soil moisture and temperature as related to grass development in the steppe of eastern Washington. Ecol. 53:419-424.

Daubenmire, R. 1974. Plants and environment. A textbook of plant autecology. 3rd ed. John Wiley \& Sons.

Environment Canada (Atmospheric Environment Service). 1974. Climate of British Columbia: Tables of temperature and precipitation. Climatic normal 1941-1970. B.C. Dep. Agr.

Environment Canada (Atmospheric Environment Service). 1977. Annual meteorological summary. Penticton, British Columbia.

Environment Canada (Atmospheric Environment Service). 1978. Annual meteorological summary. Penticton, British Columbia.

Environment Canada (Atmospheric Environment Service). 1979. Annual meteorological summary. Penticton, British Columbia.

Harper, F.E. 1969. Effects of certain climatic factors on the productivity and availability of forages on the Ashnola bighorn winter ranges. M.S. Thesis, Univ. British Columbia, Vancouver, Canada.

Harris, G.A., and C.J. Goebel. 1976. Factors of plant competition in seeding Pacific Northwest bunchgrass ranges. Wash. Agr. Exp. Sta. Bull. 820, Washington State Univ., Pullman.

Hitchcock, C.L., and A. Cronquist. 1973. Flora of the Pacific Northwest. Univ. Washington Press, Seattle.

Kelley, C.C., and R.H. Spilsbury. 1949. Soil survey of the Okanagan and Similkameen Valleys: British Columbia. Can. Dep. Agr. British Columbia Surv, Rep. 3. Kings Printer. Ottawa, Ontario, Canada. 
McLean, A. 1970. Plant communities of the Similkameen Valley, British Columbia, and their relationships to soils. Ecol. Monogr. 40:403-424.

Majak, W., and A. McLean. 1975. Variability of miserotoxin concentration in timber milkvetch. J. Range Manage. 28:362-364.

Parker, K.W. 1951. A method for measuring trend in range condition on national forest ranges. U.S. Forest Serv., Washington, D.C.

Quinton, D.A., A. McLean, and D.G. Stout. 1982. Vegetative and reproductive growth of bluebunch wheatgrass in interior British Columbia. J. Range Manage. 35:46-51.

Ratliff, R.D., and H.F. Heady. 1962. Seasonal changes in herbage weight in an annual grass community. J. Range Manage. 15:146-151.

Sauer, R.H., and D.W. Uresk. 1976. Phenology of steppe plants in wet and dry years. Northwest Sci. 50:133-139.
Stout, D.G., A. McLean, and D.A. Quinton. 1981. Growth and phenological development of rough fescue in interior British Columbia. J. Range Manage. 34:455-459.

Tisdale, E.W. 1947. The grasslands of the southern interior of British Columbia. Ecol. 28:346-382.

Tisdale, E.W., M. Hironaka, and W.L. Pringle. 1959. Observations on the autecology of Hypericum perforatum. Ecol. 40:54-62.

White, L.M. 1979. Relationships between meteorological measurements and flowering of index species to flowering of 53 plant species. Agr. Meteorol. 20:189-204.

Wikeem, B.M. 1984. Forage selection by California bighorn sheep and the effects of grazing on an Artemisia-Agropyron community in southern British Columbia. Ph.D. Thesis, Univ. British Columbia, Vancouver, Canada. 